\title{
Reproductive biology and development of sexually dimorphic structures in Aphyocharax anisitsi (Ostariophysi: Characidae)
}

\author{
Taís K. Gonçalves*, Marco A. Azevedo**, \\ Luiz R. Malabarba*,***, and Clarice B. Fialho*
}

The reproductive period of Aphyocharax anisitsi is described through the analysis of specimens collected monthly from April 2001 to March 2002 in the arroio do Salso (30²2’27"S, 5502’06"W), Rosário do Sul, Rio Grande do Sul, Brazil. The monthly variation of the Gonadosomatic Index mean (GSI) of both males and females allowed the recognition of a defined seasonal reproductive period occurring between September and February, showing a positive correlation with temperature and daylength. Absolute fecundity was 344.8 oocytes and relative fecundity 0.68 oocytes per $\mathrm{mg}$ of body weight. Absolute fecundity was correlated with standard length and total body weight. It was possible to identify two categories of males through the analysis of the number of rays bearing hooks on the anal fin: those with few or no rays bearing hooks identified as young males hatched in the last reproductive season, and those with a higher number of anal-fin rays bearing hooks identified as males that had already reproduced once or that are maturing and participating in their first reproductive period. Once developed, anal-fin rays are maintained permanently. A positive correlation was found between the GSI of maturing and mature males and the number of anal-fin rays bearing hooks from August to January. All specimens bearing gill glands were mature or undergoing maturation, and the frequency of occurrence of the gill glands increased with a rise of GSI.

O período reprodutivo de Aphyocharax anisitsi é descrito através da análise de espécimes coletados mensalmente entre abril de 2001 e março de 2002 no arroio do Salso (30²2’27"S, 5502’06"W) em Rosário do Sul, Rio Grande do Sul, Brasil. A variação mensal das médias do IGS (Índice Gonadossomático) de machos e fêmeas mostrou um período reprodutivo sazonalmente definido, ocorrendo entre os meses de setembro e fevereiro, e apresentou correlação positiva com a variação da temperatura e do fotoperíodo. A fecundidade absoluta média da espécie foi de 344,8 ovócitos. A fecundidade relativa média foi de 0,68 ovócitos por mg de peso total. A fecundidade absoluta apresentou correlação com o comprimento padrão e com o peso total. Através da análise do número de raios com ganchos da nadadeira anal dos machos foi possível identificar duas categorias, aqueles com nenhum ou poucos raios com ganchos que seriam indivíduos jovens nascidos no último período reprodutivo e que ainda não entraram em atividade reprodutiva e aqueles machos com um número alto de raios com ganchos que seriam indivíduos que já se reproduziram e mantiveram os ganchos ou que estão participando pela primeira vez do período reprodutivo. Foi observada uma correlação positiva entre o número de raios com ganchos e o IGS de machos maduros ou em maturação entre os meses de agosto a janeiro. Todos os indivíduos que apresentaram glândula branquial estavam em maturação ou maduros. A freqüência da ocorrência desta estrutura aumentou com a elevação das médias de IGS.

Key words: fin hooks, gill gland, gonadosomatic index, reproduction.

\section{Introduction}

Characiformes is a group of Neotropical and African freshwater fishes that exhibits a wide range of behaviors and comprises the most morphologically diverse assemblage among ostariophysan fishes (Vari, 1998). The family Characidae, with over 1352 species (Reis et al., 2003), is the largest within the order and one of the most diverse families of Neotropical fishes. Aphyocharax is the single genus currently in the apparently monophyletic characid subfamily Aphyocharacinae,

\footnotetext{
*Departamento de Zoologia, Universidade Federal do Rio Grande do Sul. Av. Bento Gonçalves 9500, prédio 43435. $90054-000$ Porto Alegre, RS, Brazil. (CBF) cbfialho@via-rs.net

**Museu de Ciências Naturais, Fundação Zoobotânica do Rio Grande do Sul, Rua Dr. Salvador França, 1427. $90690-000$ Porto Alegre, RS, Brazil. e-mail: marco.azevedo@fzb.rs.gov.br

***Museu de Ciências e Tecnologia, Pontifícia Universidade Católica do Rio Grande do Sul, Av. Ipiranga 6681, 90619-900 Porto Alegre, RS, Brazil.e-mail: malabarb@pucrs.br
} 
which includes a total of 10 species (Lima, 2003).

Aphyocharax anisitsi is found in the rios Paraná, Paraguay and Uruguay and the laguna dos Patos drainages in southern South America. It is a small species that reproduces by means of external fertilization. Mature males have small bony hooks on several anal and pelvic-fin rays, a putative apomorphic character shared by most characids (Malabarba \& Weitzman, 2003). Mature males of this species possess gill glands, which have thus far been described in a few characid species (Burns \& Weitzman, 1996; Bushmann et al., 2002).

In spite of reproduction being one of the most studied aspects of fishes, the available information is still very limited given the large number of fish species. Vazzoler \& Menezes (1992) estimated that information on reproductive patterns is available for only about $10 \%$ of Neotropical characiforms.

In the current report, the reproductive cycle of Aphyocharax anisitsi is described from the analysis of the monthly variations of the gonadosomatic index (GSI) and stages of gonadal maturation in both sexes. We also determine female absolute and relative fecundity, as well as the influence of water temperature, day-length, rainfall, and stomach repletion index (SRI) on the reproductive cycle. Male secondary sex characters (gill glands and anal-fin hooks), which develop during sexual maturation, are also described.

\section{Material and Methods}

Specimens of both sexes were collected monthly from April 2001 to March 2002 in the arroio do Salso $\left(30^{\circ} 22^{\prime} 27^{\prime \prime} \mathrm{S}\right.$, $\left.55^{\circ} 02^{\prime} 06^{\prime \prime} \mathrm{W}\right)$, a stream of the rio Uruguay drainage, Rosário do Sul, Rio Grande do Sul, Brazil. This stream has a sandy bottom and slow current flow. Marginal vegetation is sparse and the abundance of floating macrophytes moderate.

Specimens were obtained with a seine net $(5 \mathrm{~mm}$ mesh), and preserved in $10 \%$ formalin just after capture. Water temperature, oxygen saturation, $\mathrm{pH}$ and conductivity were measured in the field during each collection. Specimens were left in fixative a minimum of 10 days, and later transferred to $70 \%$ ethanol. Standard length (SL) and total body weight (Wt) were measured for each specimen, as well as gonad weight $(\mathrm{Wg})$ and stomach weight (Ws) after dissection. All weights were calculated to the nearest $0.0001 \mathrm{~g}$. Gonadosomatic index (GSI) and stomach repletion index (SRI) were calculated according to Vazzoler (1996): GSI $=(\mathrm{Wg} \times 100) / \mathrm{Wt}$ and SRI $=$ (Ws x 100)/Wt.

Total fecundity was estimated by counting the number of yolky oocytes in both ovaries of 10 mature females, and relative fecundity by dividing the total number of oocytes by total body weight (Adebisi, 1987). Stages of gonadal maturation were determined through macroscopic analysis following Azevedo et al. (2000) and confirmed through histological analysis, when necessary. For histology, formalin fixed gonads were dehydrated in an ethanol series, embedded in paraffin, sectioned at $0.5 \mu \mathrm{m}$ and stained with hematoxylin-eosin. The fusion of gill filaments during gill gland formation was determined using scanning electron microscopy (SEM). For SEM analysis, the first gill arch of formalin fixed and alcohol preserved specimens was extracted, dehydrated with critical point dryer and covered with coat and gold. A stereomicroscope was used to analyze the presence and number of rays bearing hooks on the anal and pelvic fins.

Correlations were calculated between GSI and abiotic factors (water temperature, day-length and rainfall) and one biotic factor (SRI) using the non-parametric test of Spearman. Correlations were also calculated between absolute fecundity and the biometric factors (SL and $\mathrm{Wt}$ ) using the correlation test of Pearson. Voucher specimens are deposited at Departamento de Zoologia of the Universidade Federal do Rio Grande do Sul fish collection, and numbered as UFRGS 6485.

\section{Results}

A total of 285 specimens were analyzed, comprising 130 males (19.59-31.62 $\mathrm{mm} \mathrm{SL})$ and 155 females $(20.80-32.31 \mathrm{~mm}$ $\mathrm{SL}$ ). Male GSI means ranged from 0.31 (March) to 1.09 (December) and female GSI means ranged from 0.45 (April) to 6.14 (January). The monthly variation of GSI of both sexes (Fig. 1) indicated a well defined reproductive period extending from September through February, which corresponds to spring and summer in the southern hemisphere. The monthly variation of mean GSI of both sexes was significantly correlated with the monthly variation of water temperature $(\mathrm{r}=$ $0.6200, p=0.0347$ for males and $r=0.5884, p=0.0489$ for females $)$ and day-length $(r=0.7692, p=0.0034$ for males and $r=0.7622, p=0.0055$ for females) (Fig. 1). A significant negative correlation with rainfall was found for females only $(\mathrm{r}=$ $0.7343, \mathrm{p}=0.0065)$. No significant correlation was found between GSI and SRI for either sex (Table 1). Absolute fecundity ranged from 203 to 491 oocytes (mean $=344.8 \pm 116.4$ ), and the mean relative fecundity was $0.68 \pm 0.14$ oocytes $/ \mathrm{mg}$ Wt. Absolute fecundity was significantly correlated with SL $(\mathrm{r}=0.7693, \mathrm{p}=0.0093)$ and $\mathrm{Wt}(\mathrm{r}=0.8337, \mathrm{p}=0.0027)$.

Table 1. Monthly mean values of GSI $( \pm$ SD $)$ and RSI $( \pm$ SD $)$ for males and females of $A$. anisitsi collected from April 2001 to March 2002 in the arroio do Salso, Rosário do Sul, RS, Brazil. GSI = Gonadosomatic Index; RSI = Stomach Repletion Index; $\mathrm{SD}=$ Standard Deviation .

\begin{tabular}{lcccc}
\hline \multicolumn{1}{c}{ Month } & GSI $( \pm$ SD) & RSI $( \pm$ SD $)$ & GSI $( \pm$ SD) & RSI $( \pm$ SD $)$ \\
\hline April & $0.68( \pm 0.28)$ & $1.13( \pm 0.22)$ & $0.45( \pm 0.11)$ & $1.08( \pm 0.35)$ \\
May & $0.58( \pm 0.25)$ & $1.43( \pm 0.18)$ & $0.85( \pm 0.27)$ & $1.72( \pm 0.52)$ \\
June & $0.63( \pm 0.0$ & $1.34( \pm 0.0)$ & $1.07( \pm 0.44)$ & $1.81( \pm 0.69)$ \\
July & $0.57( \pm 0.25)$ & $1.82( \pm 0.25)$ & $1.37( \pm 0.31)$ & $2.49( \pm 0.86)$ \\
August & $0.49( \pm 0.24)$ & $1.54( \pm 0.57)$ & $1.73( \pm 0.78)$ & $2.26( \pm 1.19)$ \\
September & $0.65( \pm 0.24)$ & $1.52( \pm 0.39)$ & $2.71( \pm 0.85)$ & $1.36( \pm 0.39)$ \\
October & $0.91( \pm 0.29)$ & $1.47( \pm 0.46)$ & $2.91( \pm 0.90)$ & $1.32( \pm 0.39)$ \\
November & $1.04( \pm 0.18)$ & $2.20( \pm 0.59)$ & $4.62( \pm 2.40)$ & $1.73( \pm 0.53)$ \\
December & $1.09( \pm 0.18)$ & $1.68( \pm 0.94)$ & $5.21( \pm 1.86)$ & $2.04( \pm 0.74)$ \\
January & $0.99( \pm 0.0$ & $1.02( \pm 0.0)$ & $6.14( \pm 3.08)$ & $1.64( \pm 0.06)$ \\
February & $0.70( \pm 0.14)$ & $1.52( \pm 0.99)$ & $4.73( \pm 2.03)$ & $1.44( \pm 0.48)$ \\
March & $0.31( \pm 0.21)$ & $1.07( \pm 0.25)$ & $0.54( \pm 0.36)$ & $1.17( \pm 0.42)$ \\
\hline
\end{tabular}




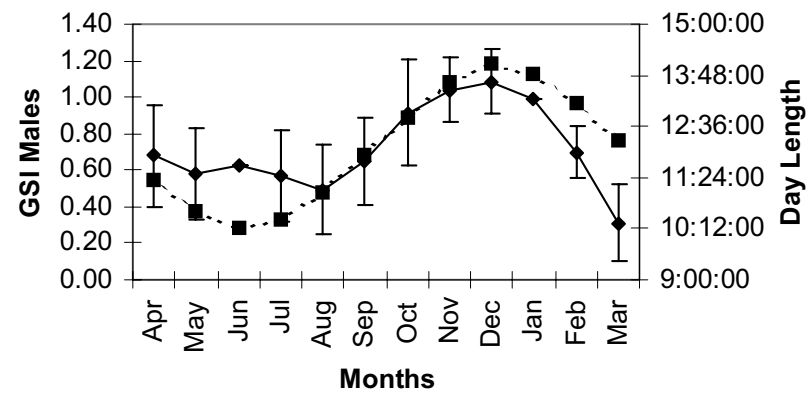

a

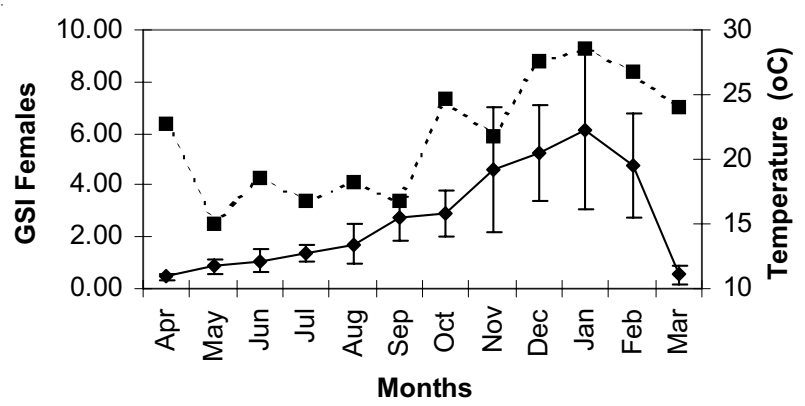

b

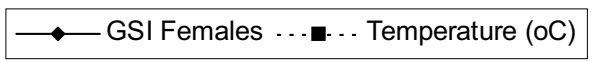

Fig. 1. Monthly variation of the mean values of GSI $( \pm \mathrm{SD})$ in males (a) and females (b) of Aphyocharax anisitsi collected from April 2001 to March 2002 in the arroio do Salso, Rosário do Sul, RS, Brazil, and monthly variation of the day-length (a) and water temperature (b) mean values. (GSI = Gonadosomatic Index; $\mathrm{SD}=\mathrm{Standard}$ Deviation represented by vertical bars).

The number of anal-fin rays in males ranged from iv (unbranched) +15 to 20 (branched). Maximal development of bony hooks on this fin was represented by the presence of hooks in the last unbranched ray and along all branched rays. All mature males examined from October through February, when the highest GSI means were seen, had a high number (11-20) of anal-fin rays with bony hooks (Fig. 2). From April through September 2001 and March 2002, however, it was possible to discern two categories of males: those with few to no rays (0-8) bearing hooks and those with a high number (11-20) of rays with hooks (Fig. 2). The range of body size of males with no hooks or fewer rays (0-8) bearing hooks is similar to and largely overlaps the range of body size of males with a greater number of anal-fin rays (11-20) bearing hooks (19.6-28.2 mm SL, mean 24.7 mm, vs. 21.5-31.6 mm SL, mean $27.8 \mathrm{~mm}$, respectively). Body size of males with few or no hooks, however, was significantly smaller than those with a greater number of rays bearing hooks when submitted to a Mann-Whitney $U$ test $(U=456, p=0.001)$. A significant correlation between GSI and number of anal-fin rays with hooks $(\mathrm{r}=0.7409, \mathrm{p}<0.001)$ was found for males from August 2001 through January 2002, when we observed a progressive increase in the number of anal-fin rays bearing hooks.

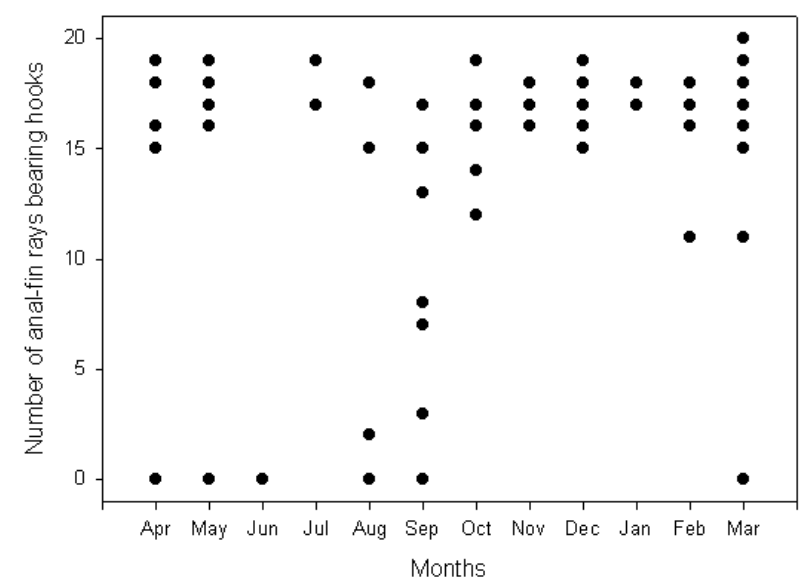

Fig. 2. Monthly variation of the number of anal fin rays bearing hooks in males of Aphyocharax anisitsi between April 2001 and March 2002 in the arroio do Salso, Rosário do Sul, RS, Brazil (each dot may represent more than one specimen). At the bottom, males with few or no hooks identified as young males that were probably hatched during the previous reproductive season. At the top, males that matured during previous reproductive season or are maturing for the first time.

Males with few to no hooks on the anal-fin rays from April through September 2001 and March 2002 were identified as young males that were probably hatched during the previous reproductive season. The presence of hooks on at least some fin rays suggest that some males had begun to mature, but once environment conditions (day-length, temperature) become unfavorable, further maturation was inhibited. Males with a high number of anal-fin rays with hooks captured outside of the reproductive period, i.e., from April to August 2001 and March 2002, have apparently already reproduced during the previous season. It appears that, once developed, the hooks remain on the anal-fin rays permanently.

Gill glands were either observed or not in males of $A$. anisitsi. All specimens that possessed distinct gill glands were males that were already mature or undergoing sexual maturation. When present, gill glands were formed from the fusion of two to five gill filaments on the first gill arch on either side of the body (Fig. 3). Higher mean GSIs were associated with a greater number of males possessing gill glands (Fig. 4). However, immature, maturing and even some mature males lacked discernible gill glands.

\section{Discussion}

According to Vazzoler and Menezes (1992), most characiforms, including several characid species, spawn during spring and summer. The peak reproductive period of Aphyocharax anisitsi also occurred during spring and summer when temperatures and day-lengths were both maximal. Indeed, in both sexes, mean monthly GSIs were significantly correlated with both water temperature and day-length, which shows an annual variation of approximately four hours. An- 


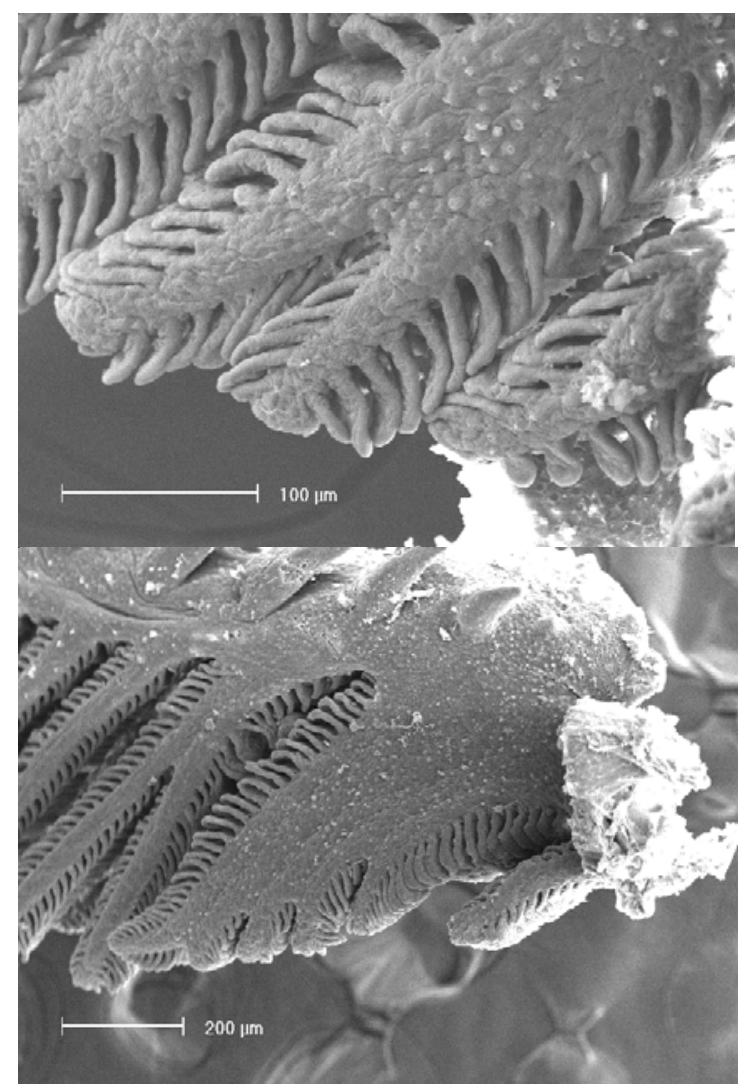

Fig. 3. Lateral view of the ventralmost portion of the first gill arch of two males of Aphyocharax anisitsi collected in February 2001 in the arroio do Salso, Rosário do Sul, RS. (A) specimen with the initial development of the gill gland seen through the fusion of two gill filaments. (B) specimen with a fully developed gill gland seen through the fusion of five gill filaments (SEM).

nual day-length variations as small as 1.6 hours have been shown to significantly influence reproduction in low-latitude fishes (Burns, 1985; Burns \& Flores, 1981). In temperate southern Brazil, the site of our collections, environmental conditions during spring and summer appear to be most favorable for the survival of the fry, when food availability is greatest.

In tropical regions, where the annual variations of water temperature and day-length may be minimal, rainfall appears to be a major environmental factor influencing reproductive cycling (Vazzoler \& Menezes, 1992). In these areas, the increase in water levels provides better shelter for the fry, as well as a more abundant food supply. On the other hand, in southern Brazil, where no definitive pattern in monthly precipitation is evident, fish reproductive cycles are generally not correlated with rainfall (Vazzoler \& Menezes, 1992). This is the case with several characid species from southern Brazil (Azevedo, 2000; Azevedo et al., 2000; Oliveira et al., 2002). However, in the present study, the mean monthly GSIs of female Aphyocharax anisitsi did show a significant negative correlation with monthly rainfall levels, although male GSIs showed no such pattern.

The positive correlations between absolute fecundity and

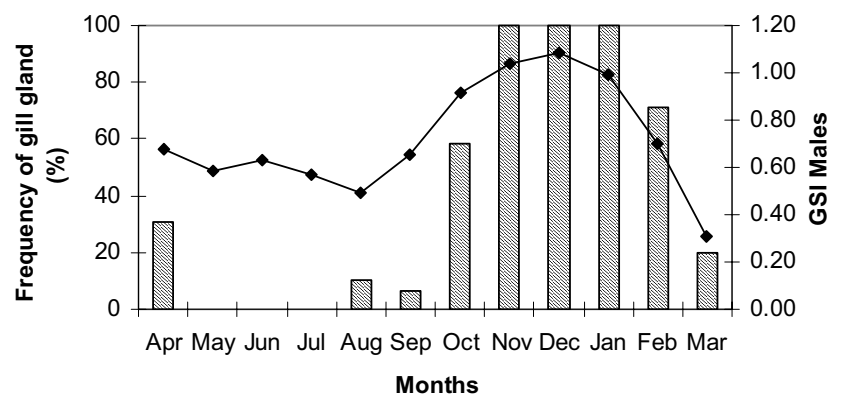

Frequency of gill gland $(\%) \multimap-$ GSI Males

Fig. 4. Monthly variation of the GSI mean values and frequency of occurrence (\%) of males of Aphyocharax anisitsi bearing gill glands, collected from April 2001 to March 2002 in the arroio do Salso, Rosário do Sul, RS, Brazil.

both SL and Wt in A. anisitsi demonstrate that larger specimens are able to produce greater numbers of eggs. Vazzoler (1996) also found that absolute fecundity increases with female development, being more related to body size than age. Differences in mean body size may explain the disparity between the values for absolute fecundity in A. anisitsi (345 oocytes, mean SL $28 \mathrm{~mm}$ ) in the present study and that of Aphyocharax alburnus (617 oocytes, mean SL $37 \mathrm{~mm}$ ) in the study of Winemiller (1989). There is little information on relative fecundity in characids. Relative fecundity allows the comparison of the energetic effort spent in egg production in species of different sizes. Table 2 presents both absolute and relative fecundity for 11 small characid species from southern Brazil. Mean relative fecundity in $A$. anisitsi was 0.68 oocytes $/ \mathrm{mg}$

Table 2. Absolute and relative mean fecundity values ( \pm Standard Deviation) of small size characids. Relative fecundity values $=$ Number of oocytes $/ \mathrm{mg}$ of total body weight.

\begin{tabular}{|c|c|c|}
\hline Species & Absolute fecundity & Relative fecundity \\
\hline $\begin{array}{l}\text { Aphyocharax anisitsi } \\
\text { This study }\end{array}$ & $344.8( \pm 116.4)$ & $0.68( \pm 0.14)$ \\
\hline $\begin{array}{l}\text { Bryconamericus iheringii } \\
\text { (Lampert, 2003) }\end{array}$ & $933.71( \pm 303.1)$ & $0.36( \pm 0.08)$ \\
\hline $\begin{array}{l}\text { Bryconamericus stramineus } \\
\text { (Lampert, 2003) }\end{array}$ & $371.3( \pm 244.6)$ & $0.35( \pm 0.08)$ \\
\hline $\begin{array}{l}\text { Cheirodon ibicuhiensis } \\
\text { (Oliveira et al., 2002) }\end{array}$ & $513( \pm 230.06)$ & $0.5( \pm 0.11)$ \\
\hline $\begin{array}{l}\text { Compsura heterura } \\
\text { (Oliveira, 2003) }\end{array}$ & $434( \pm 112)$ & 0.55 \\
\hline $\begin{array}{l}\text { Diapoma speculiferum } \\
\text { (Azevedo et al., 2000) }\end{array}$ & $491.1( \pm 159.5)$ & $0.4101( \pm 0.120)$ \\
\hline $\begin{array}{l}\text { Diapoma terofali } \\
\text { (Azevedo, pers. comm.) }\end{array}$ & $322.63( \pm 149.35)$ & $0.565( \pm 0.098)$ \\
\hline $\begin{array}{l}\text { Mimagoniates microlepis } \\
\text { (Azevedo, 2000) }\end{array}$ & $109.33( \pm 56.51)$ & $0.27( \pm 0.08)$ \\
\hline $\begin{array}{l}\text { Mimagoniates rheocharis } \\
\text { (Azevedo, 2000) }\end{array}$ & $421.05( \pm 193.5)$ & $0.356( \pm 0.098)$ \\
\hline $\begin{array}{l}\text { Odontostilbe pequira } \\
\text { (Oliveira, 2003) }\end{array}$ & $722( \pm 1.79)$ & 0.71 \\
\hline $\begin{array}{l}\text { Pseudocorynopoma doriae } \\
\text { (Azevedo et al., 2000) }\end{array}$ & $980( \pm 254.26)$ & $0.3412( \pm 0.1342)$ \\
\hline $\begin{array}{l}\text { Serrapinnus calliurus } \\
\text { (Azevedo et al., 2000) }\end{array}$ & 406 & 0.631 \\
\hline
\end{tabular}


of total body weight, demonstrating that this species expends a large amount of energy in egg production compared to other characid species of similar size.

The presence of fin hooks in males has been occasionally suggested as seasonal for some species of characid fishes (von Ihering \& Azevedo, 1936; Collette, 1977; Garutti, 1990), based on the large occurrence of fin rays with hooks in males during the reproductive season and its absence or small occurrence in the remaining periods. In other papers, these structures are considered permanent once developed (Andrade et al., 1984; Silva et al., 1996; Azevedo, 2000; Lampert, 2003). In A. anisitsi, all males captured during the reproductive season had well developed anal-fin hooks, whereas during the other months some males had anal-fin hooks and others did not. We hypothesize that these hooks, once developed, are retained by the males, and that males showing no hooks are young males that have not yet begin to mature. The statistically significant smaller size of the males without hooks than that observed in males with hooks supports this hypothesis.

Male secondary sex characters, such as fin hooks and gill glands, appear to depend on gonadal hormones, particularly androgens, for their development. Hence, their appearance and increase in size should parallel gonadal development. Supporting this is the positive correlation between mean GSI and the number of anal-fin rays bearing hooks in A. anisitsi. In addition, a greater frequency of males with developed gill glands was found during months with higher mean GSIs. In fact, during the three months of peak mean GSIs (NovemberJanuary), all males collected had gill glands. Gill glands may be involved with the production of a chemical signal related in some way with reproduction, possibly courtship and/or intermale aggression (Bushmann et al., 2002). Among characids, gill glands are found in a number of genera of the subfamily Glandulocaudinae, perhaps all genera of the subfamily Cheirodontinae, and species in the genera Bryconamericus, Knodus and Hemibrycon (Bushmann et al., 2002), Attonitus and Bryconadenos (Weitzman et al., 2005).

\section{Acknowledgements}

Financial support provided by CNPq, Brazil (proc. 464545/ 00-5; 476821/2003-7). Collection under permit of IBAMA, Brazil to LRM. Manuscript was reviewed and improved with comments by J. R. Burns and N. F. Verani.

\section{Literature Cited}

Adebisi, A. A. 1987. The relationships between the fecundities, gonadosomatic indices and eggs sizes of some fishes of Ogun River, Nigeria. Archiv fur Hydrobiologie, 111:151156.

Andrade, D. R., E. Menin \& S. P. Ribeiro. 1984. Periodicidade da característica sexual secundária em Astyanax bimaculatus (Linnaeus, 1758) Pisces, Characidae. Revista Seiva, 44:9-12.
Azevedo, M. A. 2000. Biologia reprodutiva de dois glandulocaudíneos com inseminação, Mimagoniates microlepis e Mimagoniates rheocharis (Teleostei: Characidae), e características de seus ambientes. Unpubl. Master thesis. Universidade Federal do Rio Grande do Sul, Porto Alegre, Brazil. 84p.

Azevedo, M. A., L. R. Malabarba \& C. B. Fialho. 2000. Reproductive biology of the inseminating glandulocaudine Diapoma speculiferum Cope (Teleostei: Characidae). Copeia, 2000:983-989.

Burns, J. R. 1985. The effect of low-latitude photoperiods on the reproduction of female and male Poeciliopsis gracilis and Poecilia sphenops. Copeia, 1985:961-965.

Burns, J. R. \& J. A. Flores. 1981. Reproductive biology of the cuatro ojos, Anableps dowi (Pisces: Anablepidae), from El Salvador and its seasonal variations. Copeia, 1981:2532.

Burns, J. R. \& S. H. Weitzman. 1996. Novel gill-derived gland in the male swordtail characin, Corynopoma riisei (Teleostei: Characidae: Glandulocaudinae). Copeia, 1996:627-633.

Bushmann, P. J., J. R. Burns \& S. H. Weitzman. 2002. Gillderived glands in glandulocaudine fishes (Teleostei: Characidae: Glandulocaudinae). Journal of Morphology, 3:187-195.

Collette, B. B. 1977. Epidermal breeding tubercles and bony contact organs in fishes. Symposium of the Zoological Society of London, 39:25-268.

Garutti, V. 1990. Caráter sexual secundário em Astyanax bimaculatus (Ostariophysi, Characidae), relacionado às nadadeiras anal e pélvicas. Naturalia 15:109-119.

von Ihering, R. \& P. Azevedo. 1936. As piabas dos açudes nordestinos (Characidae: Tetragonopterinae). Archivos do Instituto Biológico de São Paulo, 7:75-106.

Lampert, V. R. 2003. Biologia reprodutiva de duas espécies do gênero Bryconamericus (Characidae: Tetragonopterinae) dos sistemas dos rios Jacuí e Uruguai, RS. Unpubl. Master dissert. Universidade Federal do Rio Grande do Sul, Porto Alegre, Brazil. 73p.

Lima, R. 2003. Subfamily Aphyocharacinae (Characins), p. 197199. In: Check List of the Freshwater Fishes of South and Central America. R. E. Reis, S. O. Kullander and C. J. Ferraris Jr. (Eds.). Edipucrs, Porto Alegre, Brazil. 729p.

Malabarba, L. R. \& S. H. Weitzman. 2003. Description of a new genus with six new species from Southern Brazil, Uruguay and Argentina, with a discussion of a putative characid clade (Teleostei: Characiformes: Characidae). Comunicações do Museu de Ciências e Tecnologia PUCRS, Série Zoologia, 16:65-151.

Oliveira, C. L. C. 2003. Análise comparada de caracteres reprodutivos e da glândula branquial de duas espécies de Cheirodontinae (Teleostei: Characidae). Unpublished Master Thesis. Universidade Federal do Rio Grande do Sul, Porto Alegre, Brazil. 80p.

Oliveira, C. L. C., C. B. Fialho \& L. R. Malabarba. 2002. Período reprodutivo, desova e fecundidade de Cheirodon 
ibicuhiensis Eigenmann, 1915 (Ostariophysi: Characidae) do arroio Ribeiro, Rio Grande do Sul, Brasil. Comunicações do Museu de Ciências e Tecnologia PUCRS, Série Zoologia, 15:3-14.

Reis, R. E., S. O. Kullander \& C. J. Ferraris Jr. 2003. Check List of the Freshwater Fishes of South and Central America. Edipucrs, Porto Alegre, Brazil. 729p.

Silva, J. V., D. R. Andrade \& W. Y. Okano. 1996. Desenvolvimento sexual e crescimento de lambaristambiú, Astyanax bimaculatus Linnaeus, 1758 submetidos a diferentes tipos de alimentação. Arquivo Brasileiro de Medicina Veterinária e Zootecnia, 48:3-38.

Vari, R. P. 1998. Higher Level, Phylogenetic Concepts within Characiformes (Ostariophysi), a Historical Review, p. 111122. In: Phylogeny and classification of Neotropical fishes, L. R. Malabarba, R. E. Reis, R. P. Vari, Z. M. S. Lucena, and C.A. S. Lucena (Eds.). Edipucrs, Porto Alegre, Brazil. 623p.
Vazzoler, A. E. 1996. Biologia da reprodução de peixes teleósteos: teoria e prática. Editora da Universidade Estadual de Maringá, Maringá, Brazil. 169p.

Vazzoler, A. E. \& N. A. Menezes. 1992. Síntese de conhecimento sobre o comportamento reprodutivo dos Characiformes da América do Sul (Teleostei, Ostariophysi). Revista Brasileira de Biologia, 52(4):627-640.

Weitzman, S. H., N. A. Menezes, H.-G. Evers \& J. R. Burns. 2005. Putative relationships among inseminating and externally fertilizing characids, with a description of a new genus and species of Brazilian inseminating fish bearing an anal-fin gland in males (Characiformes: Characidae). Neotropical Ichthyology, 3(3):329-360.

Winemiller, K. O. 1989. Patterns of variation in life history among South American fishes in seasonal environments. Oecologia 81:225-241.

Received April 2005

Accepted September 2005 